OPEN ACCESS

Edited by:

Tim Ulinski,

Hôpital Armand Trousseau, France

Reviewed by:

Vera Hermina Koch,

University of São Paulo, Brazil

Se Jin Park,

Yonsei University, South Korea

*Correspondence:

Maysoun Al Rushood

maysoun.alrushood@ku.edu.kw

Specialty section:

This article was submitted to

Pediatric Nephrology,

a section of the journal

Frontiers in Pediatrics

Received: 04 August 2020 Accepted: 28 October 2020 Published: 19 November 2020

Citation:

Al Rushood M, Al-Eisa AA and Haider MZ (2020) Interleukin-4 and Interleukin-13 Gene Polymorphisms in

Children With Idiopathic Nephrotic

Syndrome. Front. Pediatr. 8:591349.

doi: 10.3389/fped.2020.591349

\section{Interleukin-4 and Interleukin-13 Gene Polymorphisms in Children With Idiopathic Nephrotic Syndrome}

\author{
Maysoun Al Rushood*, Amal A. Al-Eisa and Mohammad Z. Haider \\ Department of Pediatrics, Faculty of Medicine, Health Sciences Center, Kuwait University, Kuwait City, Kuwait
}

Background: Idiopathic Nephrotic syndrome (INS) is an immune-mediated disease in which a number of cytokines, including IL-4 and IL-13, have been implicated in the pathogenesis. Cytokine gene polymorphisms might affect their levels and activity. Therefore, may affect INS susceptibility and response to treatment. The aim of the study was to determine the association of IL-4 and IL-13 gene polymorphisms and INS susceptibility and their effects on steroid responsiveness in children.

Methods: The polymorphisms in IL-4 and IL-13 genes were detected by PCR-RFLP in 155 INS patients and 64 controls.

Results: A total of 132 steroid-sensitive (SS) and 23 steroid resistance (SR) INS patients; mean age $7.3 \pm 4.0$ years, were included. Male: Female ratio was 2:1. No significant statistical differences were detected in the frequency of CC, CT, and $\Pi$ genotypes of IL-4 gene compared to controls ( $P=0.57,0.61$, and 1.00 , respectively). There was no significant difference in the T and C-allele frequencies, in SS and SR subgroups. Analysis of IL-13 gene polymorphism also did not show significant statistical differences in the frequency of $Q Q, R Q$, and $R R$ genotypes compared to controls $(P=0.74,1.00$, and 0.68 , respectively). No significant difference was found in the $Q$ and $R$-allele frequency. However, the heterozygous RQ genotype of the IL13 gene was significantly higher in SS INS patients compared to the SR INS cases $(P=0.04)$.

Conclusion: Our findings did not show an association between IL-4 and IL-13 gene polymorphisms and INS susceptibility. However, IL-13 RQ genotype was expressed more in children with INS who are steroid sensitive.

Keywords: interleukin-4, interleukin-13, nephrotic syndrome, gene polymorphisms, cytokine, steroids

\section{INTRODUCTION}

Idiopathic nephrotic syndrome (INS) is the most frequent form of nephrotic syndrome in children, representing more than $90 \%$ of cases between the age of 1 to 10 years (1). Immunological disturbances, especially $\mathrm{T}$ cell imbalance, have been implicated in the pathogenesis of the disease $(1,2)$. This association was suggested by the response to immunosuppressive treatment and the association between the disease with atopy and elevated serum $\operatorname{IgE}$ levels $(1,2)$.

T helper cells (Th2) with its signature cytokines such as IL-4 and IL-13 have been studied as potential important role players in the pathogenesis of the INS $(3,4)$. IL-4 is a Th2 cytokine produced by basophils, mast cells and activated TH2 cells (5), and plays an essential role in IgE 
regulation, Th2 differentiation, Th1 inhibition and induction and maintenance of allergy $(6,7)$. It might also act as an anti-tumor and an anti-inflammatory agent $(8,9)$.

On the other hand, IL-13 is an immunoregulatory protein produced by T-cells subsets, basophils, eosinophils and mast cells. It is believed to be an important mediator in allergic disease as its levels and genetic polymorphism variants have been shown to be associated with elevated serum IgE levels in atopic and asthmatic patients of different racial backgrounds (10-13).

Both IL-4 and IL-13 genes are located in a region of $140 \mathrm{~kb}$ on chromosome 5q31-33 that codes for a cluster of Th2 cytokines $(10,14)$. They share a common IL-4 receptor $\alpha$ chain (IL4 RA) in the multimeric IL-4 and IL-13 receptor complexes (15). Therefore, they share many biological activities that affect clinical conditions.

Gene Polymorphisms in the regulatory regions of these cytokines can influence the amount of cytokine produced as well as their biological activity and potency at their receptor sites (14). Cytokine gene polymorphism including that of IL-4 and IL-13 in nephrotic syndrome of children with an Arab race has not been explored previously. The aim of this study is to determine any association between IL-4 and cytokine IL-13 gene polymorphisms with the susceptibility to INS in Kuwaiti children and their effects on response to steroid treatment.

\section{METHODS}

Children less than 12 years of age with a confirmed diagnosis of Idiopathic nephrotic syndrome (INS) were included in this study. All had INS with a clinical and/or histopathological diagnosis of MCNS. Subjects were evaluated at a specialized pediatric nephrology clinic in Mubarak Al-Kabir University Hospital during the period 2012-2018. INS was defined as the presence of generalized edema, nephrotic- range proteinuria, hypoalbuminemia with or without hyperlipidemia (16). A total of 155 children were included. Patients were subdivided according to their response to steroids into steroid sensitive (SS) and steroid resistant (SR). Steroid responsiveness was defined as the disappearance of proteinuria (negative to trace in a urine dipstick for 3 consecutive days, or a urine protein/creatinine level of $<0.2$ ) within the first 4 -week course of full dose prednisolone therapy $\left(60 \mathrm{mg} / \mathrm{M}^{2} /\right.$ day $)$. Steroid resistance was defined as the persistence of proteinuria after a 4-week course of full dose prednisolone. Patients with poor compliance and not on regular follow-up were excluded as well as those with infrequent relapses. All SSNS patients were in full remission at the time of the study.

All patients underwent a thorough physical examination by an experienced pediatrician. A total of 64 age and gender- matched healthy children of the same ethnic background, were included as controls. All were examined by a senior pediatrician to exclude any renal disease. Controls were selected from patients visiting Hospital's Emergency Department for minor illnesses such as upper respiratory tract infection or acute gastroenteritis.

In all the study subjects (patients and controls), tests for blood urea, serum creatinine, total protein, albumin level and a complete lipid profile were carried out. Urine protein: creatinine ratio was also determined for all the study subjects.

At the end of the study, all SSNS patients had normal serum creatinine. Sixty-five percent of the patients were in remission for more than 6 months, while 35\% continued to relapse, but less frequently, despite receiving second-line immunosuppressive treatment. For SSNS patients, renal biopsy was performed for steroid dependent patients and for those with frequent relapses ( $>6$ relapses/year) before initiating cytotoxic therapy.

Genetic study was done in 12 SRNS patients and they were NPHS1 negative. The genetic study for the rest of the SRNS patients was not available as it should be sent outside the country.

\section{Genotyping of IL4 and IL13 Gene Polymorphisms}

DNA was isolated from the peripheral leukocytes using a standard method (17). The genotypes were determined by PCRRFLP (polymerase chain reaction-restriction fragment length polymorphism) method using the primers listed below $(18,19)$ :

\section{IL-4 Gene C590T Polymorphism}

Forward primer: 5'-ACTAGGCTCACCTGATACG-3'

Reverse primer: 5'-GTTGTAATGCAGTCCTCCTG-3'

The PCR reactions were carried out in a total volume of $25 \mu \mathrm{l}$ containing $100 \mathrm{ng}$ of genomic DNA, 10 pmoles of each primer, $2 \mathrm{mM} \mathrm{MgCl}_{2}, 0.2 \mathrm{mM}$ deoxynucleotides (dNTPs), $1 \times$ buffer, and $2 \mathrm{U}$ of Taq DNA polymerase. The amplification was performed for 35 cycles with an annealing temperature of $58^{\circ} \mathrm{C}$ for $1 \mathrm{~min}$ for the IL-4 gene C590T polymorphism. The $\mathrm{C}->\mathrm{T}$ transition at codon 590 of the IL- 4 gene abolished a restriction site for $B s m \mathrm{~F} 1$ in the $\mathrm{T}$-allele. The polymorphism was identified by $B s m F 1$ restriction endonuclease digestion of the PCR-amplified fragment. The cleavage products were analyzed by $2 \%$ agarose gel electrophoresis and visualized under UV light after staining with ethidium bromide. The product sizes were 192 and $60 \mathrm{bp}$ for the $\mathrm{C}$-allele and $252 \mathrm{bp}$ for the T-allele, respectively.

\section{IL-13 Gene Polymorphism}

The IL-13 gene polymorphisms R130Q (rs20541) and IL-13 gene promoter polymorphism (C- $1112 \mathrm{~T}$ ) was determined by PCR-RFLP methods described earlier $(18,19)$. The PCR primer sequences used were:

Sense primer: 5 -CTTCCGTGAGGACTGAATGAGAC GGTC-3'

Antisense primer: $5^{\prime}$-GCAAATAATGATGCTTTCGAAGTT TCAGTGGA-3'

For the R130Q polymorphism, amplification was carried out after denaturation at $94^{\circ} \mathrm{C}$ for $5 \mathrm{~min}$ followed by 35 cycles of $94^{\circ} \mathrm{C}$ for $45 \mathrm{~s}, 67^{\circ} \mathrm{C}$ for $45 \mathrm{~s}$ and $72^{\circ} \mathrm{C}$ for $30 \mathrm{~s}$ followed by an extension at $72^{0} \mathrm{C}$ for $5 \mathrm{~min}$. The PCR products were cleaved with restriction enzyme NlaIV $(0.5 \mathrm{U})$ at $37^{\circ} \mathrm{C}$ for $3 \mathrm{~h}$ and analyzed by agarose gel electrophoresis as described earlier. The expected cleavage products were 210 and 26 bp when a normal R130genotype is present and in the case of mutant $-130 \mathrm{Q}$ genotype the expected product size $178 \mathrm{bp}, 32$ and $26 \mathrm{bp}$, respectively. 


\section{Statistical Analysis}

The genotypes were determined by gene counting and the data was analyzed using the Chi-squared test and the Fisher's exact test. Odds Ratio (OR) was calculated with 95\% Confidence Interval (CI). $P$-values of 0.05 or less were considered as statistically significant.

Ethical approval was obtained from the Health Sciences Center Committee for the Protection of Human Subjects in Research, Kuwait University, as well as, Ministry of Health Ethics Committee. An informed consent was obtained from care givers of both patients and controls as per guidelines of the Committees.

\section{RESULTS}

The study included a total of 155 Kuwaiti children with INS. Of these, 132 were steroid-sensitive (SS) and 23 were steroid resistant (SR). The mean age in the INS patient group was 7.6 \pm 4.3 years and Male: Female ratio was 2:1. The clinical and biochemical characteristics of INS patients and controls have been presented in Table 1. A total of 83 patients had history of atopy $(53.5 \%)$, with some having more than one form of atopy. Asthma was reported in 53 patients (34\%), eczema in 46 patients $(27 \%)$, allergic conjunctivitis in $11(7 \%)$, and allergic rhinosinusitis in 7 patients (4.5\%). Food allergy was not reported in any patient. Atopy was not reported in any of the controls.

Genotype analysis of IL-4 gene polymorphism was inconclusive in 2 INS patients of the SS subgroup which were excluded from the statistical analysis for IL-4 gene polymorphism. From a total of 153 INS subjects and 64 controls, the CC genotype of IL-4 gene polymorphism was detected in $64 \%$ of the INS patients compared to $69.5 \%$ in the controls $(P$ $=0.57$ ). The heterozygous CT genotype was detected in $30 \%$ of INS patients compared to $25.5 \%$ in the controls $(P=0.61)$. The TT-genotype was detected in $6 \%$ of INS patients and in $5 \%$ of the controls $(P=1.00)$. The $\mathrm{C}$-allele frequency in homozygous and heterozygous forms was found in $94 \%$ of INS patients compared to $95 \%$ of the controls $(P=1.00)$. The T-allele frequency in homozygous and heterozygous forms was found in $35.7 \%$ of

TABLE 1 | Clinical and laboratory data of Kuwaiti children with Idiopathic Nephrotic Syndrome (INS) and the controls.

\begin{tabular}{|c|c|c|c|c|}
\hline Range & & $\begin{array}{l}\text { INS patients } \\
\quad(n=155)\end{array}$ & $\begin{array}{l}\text { Controls } \\
(n=64)\end{array}$ & Normal \\
\hline Mean age (years) & & $7.6 \pm 4.3$ & $7.1 \pm 3.7$ & \\
\hline \multirow[t]{2}{*}{ Gender } & Male & 104 & 42 & \\
\hline & Female & 51 & 22 & \\
\hline Atopy $(n)$ & & $83(53.5 \%)$ & $0(0 \%)$ & \\
\hline Mean serum creatinine $(\mu \mathrm{mol} / \mathrm{L})$ & & $47 \pm 7$ & $56 \pm 8$ & $(15-88)$ \\
\hline Mean serum protein (g/L) & & $50 \pm 2$ & $73 \pm 2$ & $(68-80)$ \\
\hline Mean serum albumin (g/L) & & $21 \pm 3$ & $34 \pm 3$ & $(30-40)$ \\
\hline Mean serum cholesterol (mmol/L) & & $6.5 \pm 0.4$ & $3.2 \pm 0.6$ & $(3.1-5.2)$ \\
\hline Mean UP: Cr ratio* (mg/mg) & & $2.8 \pm 0.7$ & $0.02 \pm 0.05$ & $(\leq 0.2)$ \\
\hline
\end{tabular}

*UP, Urine Protein; $\mathrm{Cr}$, Creatinine.
INS patients compared to $30.5 \%$ of the controls $(P=0.57)$. Table 2 summarized the gene and allele frequency of IL-4 gene polymorphism in both patients and controls. No significant difference was detected in any of the genotype frequencies between the SS and SR sub-groups when compared with each other or when compared to the controls (Table 3).

In the case of IL-13 gene polymorphism, genotyping was conclusive for all the 155 INS patients and 64 controls and the results have been presented in Table 4. The QQ genotype of IL-13 gene polymorphism was detected in $70.3 \%$ of the INS patients compared to $73.4 \%$ of the controls $(P=0.74)$. The heterozygous RQ genotype was detected in $25.8 \%$ of INS patients compared $28 \%$ of the controls $(P=1.0)$. The RRgenotype was detected in $3.9 \%$ of INS patients and $1.6 \%$ of the controls $(P=0.68)$. The $\mathrm{Q}$-allele frequency in homozygous and heterozygous forms was found in $83.2 \%$ of INS patients compared to $86 \%$ of the controls $(P=0.57)$. The R-allele frequency in homozygous and heterozygous forms was found in $16.7 \%$ of INS patients compared to $14 \%$ of the controls $(P=0.57)$. When the genotype frequencies were compared between the SS and SR sub-groups, only the RQ genotype showed a statistically significant association with steroid sensitivity ( $P=0.04$; Table 5).

The data of SS patients and SR patients were studied separately and compared to controls. When IL-4 gene polymorphisms data of SR and SS patients were compared to controls separately, no significant differences in the genotype or allele frequencies were detected, as shown in Tables 6, 7 .

Similarly, IL-13 gene polymorphisms data of SR and SS patients were compared to controls separately. No significant differences in the genotype or allele frequencies were detected, when each sub-group compared to controls, as shown in Tables 8, 9.

TABLE 2 | Interlukin-4 gene polymorphism in Kuwaiti children with INS and the controls.

\begin{tabular}{lccccc} 
Genotype & INS (\%) & $\begin{array}{c}\text { Controls (\%) } \\
(\boldsymbol{n}=\mathbf{6 4 )}\end{array}$ & $\begin{array}{c}\text { Odds ratio } \\
\text { (OR) }\end{array}$ & $\begin{array}{c}\text { 95\% confidence } \\
\text { Interval (Cl) }\end{array}$ & $\boldsymbol{P}$-values \\
\hline CC & $99(64.71)$ & $44(68.75)$ & 0.83 & $0.45-1.56$ & 0.68 \\
CT & $45(29.41)$ & $17(26.56)$ & 1.15 & $0.59-2.22$ & 0.79 \\
TT & $9(5.88)$ & $3(4.69)$ & 1.27 & $0.33-4.86$ & 1.00 \\
C allele & $243 / 306$ & $105 / 128$ & 0.84 & $0.49-1.44$ & 0.62 \\
T allele & $63 / 306$ & $23 / 128$ & 1.18 & $0.69-2.01$ & 0.62 \\
\hline
\end{tabular}

TABLE 3 | Comparison of IL-4 gene polymorphism genotype and allele frequencies between steroid sensitive (SS) and steroid resistant (SR) Kuwaiti INS patients.

\begin{tabular}{lccccc}
\hline Genotype & $\begin{array}{c}\text { SS (\%) } \\
\boldsymbol{n}=\mathbf{1 3 0}\end{array}$ & $\begin{array}{c}\text { SR (\%) } \\
(\boldsymbol{n}=\mathbf{2 3})\end{array}$ & $\begin{array}{c}\text { Odds ratio } \\
\text { (OR) }\end{array}$ & $\begin{array}{c}\text { 95\% confidence } \\
\text { interval (CI) }\end{array}$ & $\boldsymbol{P}$-values \\
\hline CC & $83(63.85)$ & $16(69.57)$ & 0.77 & $0.29-2.01$ & 0.64 \\
CT & $40(30.77)$ & $5(21.74)$ & 1.60 & $0.55-4.61$ & 0.46 \\
TT & $7(5.38)$ & $2(8.69)$ & 0.59 & $0.12-3.08$ & 0.63 \\
C allele & $226 / 260$ & $37 / 46$ & 1.62 & $0.72-3.65$ & 0.25 \\
T allele & $54 / 260$ & $9 / 46$ & 1.08 & $0.49-2.37$ & 1.00
\end{tabular}


TABLE 4 | Genotype and allele frequencies of Interleukin-13 gene polymorphism in Kuwaiti children with INS and controls.

\begin{tabular}{lccccc}
\hline Genotype & INS (\%) & Controls (\%) & Odds ratio & 95\% confidence & P-values \\
& $\boldsymbol{n}=\mathbf{1 5 5}$ & $(\boldsymbol{n}=\mathbf{6 4 )}$ & (OR) & interval (CI) & \\
\hline $\mathrm{QQ}$ & $109(70.32)$ & $47(73.44)$ & 0.86 & $0.45-1.65$ & 0.74 \\
$\mathrm{RQ}$ & $40(25.81)$ & $16(25.0)$ & 1.04 & $0.53-2.04$ & 1.00 \\
$\mathrm{RR}$ & $6(3.87)$ & $1(1.56)$ & 2.54 & $0.29-21.52$ & 0.68 \\
$\mathrm{Q}$ allele & $258 / 310$ & $110 / 128$ & 0.81 & $0.45-1.45$ & 0.57 \\
$\mathrm{R}$ allele & $52 / 310$ & $18 / 128$ & 1.23 & $0.69-2.20$ & 0.57 \\
\hline
\end{tabular}

TABLE 5 | Comparison of IL-13 gene polymorphism genotype and allele frequencies between steroid sensitive (SS) and steroid resistant (SR) Kuwaiti INS patients.

\begin{tabular}{lccccc}
\hline Genotype & SS (\%) & SR (\%) & Odds ratio & 95\% confidence & P-values \\
& $\boldsymbol{n}=\mathbf{1 3 2}$ & $(\boldsymbol{n}=\mathbf{2 3})$ & (OR) & interval (CI) & \\
\hline $\mathrm{QQ}$ & $90(68.18)$ & $19(82.60)$ & 0.45 & $0.14-1.41$ & 0.22 \\
$\mathrm{RQ}$ & $38(28.79)$ & $2(8.70)$ & 4.25 & $0.95-19.00$ & 0.04 \\
$\mathrm{RR}$ & $4(3.03)$ & $2(8.70)$ & 0.33 & $0.05-1.90$ & 0.22 \\
Q allele & $218 / 264$ & $40 / 46$ & 0.71 & $0.28-1.78$ & 0.53 \\
$\mathrm{R}$ allele & $46 / 264$ & $6 / 46$ & 1.41 & $0.56-3.51$ & 0.53 \\
\hline
\end{tabular}

TABLE 6 | Comparison of IL-4 gene polymorphism genotype and allele frequencies between Steroid Sensitive (SS) patients and controls.

\begin{tabular}{lccccc}
\hline Genotype & SS (\%) & Controls (\%) & Odds ratio & 95\% confidence & P-values \\
& $\boldsymbol{n}=\mathbf{1 3 0}$ & $(\boldsymbol{n}=\mathbf{6 4})$ & (OR) & interval (CI) & \\
\hline CC & $83(63.85)$ & $44(68.75)$ & 0.80 & $0.42-1.52$ & 0.61 \\
CT & $40(30.77)$ & $17(26.56)$ & 1.23 & $0.63-2.40$ & 0.66 \\
$\Pi T$ & $7(5.38)$ & $3(4.69)$ & 1.16 & $0.29-4.63$ & 1.00 \\
C allele & $226 / 260$ & $105 / 128$ & 1.46 & $0.82-2.60$ & 0.26 \\
T allele & $54 / 260$ & $23 / 128$ & 1.20 & $0.70-2.06$ & 0.61 \\
\hline
\end{tabular}

TABLE 7 | Comparison of IL-4 gene polymorphism genotype and allele frequencies between Steroid Resistant (SR) patients and controls.

\begin{tabular}{lccccc}
\hline Genotype & $\begin{array}{c}\text { SR (\%) } \\
(\boldsymbol{n}=\mathbf{2 3})\end{array}$ & $\begin{array}{c}\text { Controls (\%) } \\
(\boldsymbol{n}=\mathbf{6 4})\end{array}$ & $\begin{array}{c}\text { Odds ratio } \\
\text { (OR) }\end{array}$ & $\begin{array}{c}\text { 95\% confidence } \\
\text { interval (CI) }\end{array}$ & $\boldsymbol{P}$-values \\
\hline CC & $16(69.57)$ & $44(68.75)$ & 1.04 & $0.37-2.92$ & 1.00 \\
CT & $5(21.74)$ & $17(26.56)$ & 0.77 & $0.25-2.39$ & 0.78 \\
TT & $2(8.69)$ & $3(4.69)$ & 1.94 & $0.30-12.40$ & 0.60 \\
C allele & $37 / 46$ & $105 / 128$ & 0.90 & $0.38-2.12$ & 0.83 \\
T allele & $9 / 46$ & $23 / 128$ & 1.11 & $0.47-2.62$ & 0.83 \\
\hline
\end{tabular}

\section{DISCUSSION}

The immunopathogenesis of INS has been studied extensively during the recent years $(1,5,10)$. The effects of various cytokines on the glomerular basement membrane in the kidneys is widely supported by many studies on different populations $(1,5,10)$. IL-4 and IL-13 are two important mediators which have recently attracted attention in studies exploring the pathogenesis of
TABLE 8 | Comparison of IL-13 gene polymorphism genotype and allele frequencies between Steroid Sensitive (SS) patients and controls.

\begin{tabular}{lccccc}
\hline Genotype & SS (\%) & Controls (\%) & Odds ratio & 95\% confidence & P-values \\
& $\boldsymbol{n}=\mathbf{1 3 2}$ & $(\boldsymbol{n}=\mathbf{6 4})$ & (OR) & interval (Cl) & \\
\hline QQ & $90(68.18)$ & $47(73.44)$ & 0.78 & $0.40-1.51$ & 0.56 \\
RQ & $38(28.79)$ & $16(25.0)$ & 1.21 & $0.61-2.39$ & 0.70 \\
RR & $4(3.03)$ & $1(1.56)$ & 1.97 & $0.22-17.99$ & 1.00 \\
Q allele & $218 / 264$ & $110 / 128$ & 0.78 & $0.43-1.40$ & 0.48 \\
R allele & $46 / 264$ & $18 / 128$ & 1.29 & $0.71-2.33$ & 0.48 \\
\hline
\end{tabular}

TABLE 9 | Comparison of IL-13 gene polymorphism genotype and allele frequencies between Steroid Resistant (SR) patients and controls.

\begin{tabular}{lccccc}
\hline Genotype & $\begin{array}{c}\text { SR (\%) } \\
(\boldsymbol{n}=\mathbf{2 3})\end{array}$ & $\begin{array}{c}\text { Controls (\%) } \\
(\boldsymbol{n}=\mathbf{6 4})\end{array}$ & $\begin{array}{c}\text { Odds ratio } \\
\text { (OR) }\end{array}$ & $\begin{array}{c}\text { 95\% confidence } \\
\text { interval (CI) }\end{array}$ & $\boldsymbol{P}$-values \\
\hline $\mathrm{QQ}$ & $19(82.60)$ & $47(73.44)$ & 1.72 & $0.51-5.78$ & 0.57 \\
$\mathrm{RQ}$ & $2(8.70)$ & $16(25.0)$ & 0.29 & $0.06-1.36$ & 0.14 \\
$\mathrm{RR}$ & $2(8.70)$ & $1(1.56)$ & 6.00 & $0.52-69.62$ & 0.17 \\
$\mathrm{Q}$ allele & $40 / 46$ & $110 / 128$ & 1.09 & $0.40-2.94$ & 1.00 \\
$\mathrm{R}$ allele & $6 / 46$ & $18 / 128$ & 0.92 & $0.34-2.47$ & 1.00 \\
\hline
\end{tabular}

INS. As many INS patients commonly develop atopy, and IL4 and IL-13 are the major mediators involved in that process, it was not surprising to incriminate these two cytokines in the immune-pathogenesis of the INS. Several previous reports have demonstrated that both these cytokines share a number of biological activities including IgE isotope switching, CD23 induction and stimulation of eosinophils activity as they both share a common IL-4 receptor alpha chain (IL-4RA) in the multicentric IL-4 and IL-13 receptor complexes $(5,6,8,15)$.

In the present study, we did not find an association between IL-4 or IL-13 gene polymorphism and predisposition to INS in Kuwaiti Arab children.

Many previous studies reported conflicting results $(2,10$, 20). When our findings were compared with other populations worldwide, our results were consistent with data obtained from Caucasians in the UK where IL-4 gene polymorphism was studied in 100 patients and 63 controls with no significant difference between allele distribution in INS patients and the controls (2). However, Kobayashi et al. (20) studied IL-4 gene polymorphism in 58 Japanese children and found that the frequency of the $T$ allele was significantly lower in INS group than the controls. It has been previously reported that $\mathrm{T}$ allele of the 590C/T polymorphism was associated with increased IL4 gene promoter activity $(21,22)$. Another study carried out in India on 150 children with INS, demonstrated that IL-4-C590T polymorphism may influence the prognosis and the clinical course of the disease (23).

Our study did not show any association between IL-13 gene polymorphism and susceptibility of children with an Arab racial background to INS. However, the RQ genotype was associated with steroid sensitivity. 
These findings were consistent with studies reported in different other populations worldwide. Data in both Asian and Caucasian populations suggest that there is no association of IL-13 gene polymorphism with susceptibility to minimal change nephrotic syndrome $(10,24,25)$. Similar results have been reported from British INS patients (24) as well as on German INS patients (25). In Singapore Asian children also, no significant association of IL-13 gene polymorphism with INS was detected (10).

The lack of association of both $1 \mathrm{~L}-4$ as well as IL-13 gene polymorphisms and INS reported in our study as well as other studies seems to be unexpectedly surprising knowing the previously documented effects of both these cytokines in kidneys. Many previous in vivo as well as in vitro studies had supported the important roles of both cytokines and their receptors in the pathogenesis of INS. Podocytes in the glomerular basement membranes in kidneys of express receptors for both interleukins IL-4 and IL-13 $(26,27)$. These cytokines have been shown in vitro to have direct effects on podocyte mediator production and barrier function (26-28). A mechanism whereby excess IL13 might induce nephrotic syndrome is illustrated by changes in podocyte protein trafficking and proteolytic enzyme secretion seen when these cells are incubated with IL-4 or IL-13 in vitro (29).

Another intriguing animal study directly addressed the role of IL-13 by overexpressing it in the rats and reported that an MCN-like nephropathy was induced, with changes in podocyte structure and gene expression similar to those seen in human diseases (30).

Moreover, Van den Berg showed the presence of IL-13 receptors on glomerular epithelial cells, the stimulation of which, resulted in a decrease in the transepithelial electrical resistance suggesting a possible direct effect of this cytokine on the podocytes and its function in preserving circulatory albumin and preventing albuminuria, which is the hallmark of INS (27). It has been reported that children with nephrotic syndrome who had higher initial serum IgE levels, had higher relapsing rates, longer duration of steroid therapy before remission and higher serum IL-4 and IL-5 levels (31).

A dysfunctional glomerular filtration barrier characterizes nephrotic syndrome, the pathophysiology of which is highly complex. T cells, mainly Th2 and Th17, play an important role. The upregulation of specific cytokines (IL-4, IL-5, IL-9, and IL-13) was previously shown to promote the development of NS (32). Therefore, studying the gene polymorphisms of these cytokines is essential.

Our study might be limited by a relatively small sample size. It would be prudent to have the serum cytokine levels for correlation. Despite being a single center study, ours is the focal center for nephrotic syndrome in the entire country

\section{REFERENCES}

1. Davin JC. The glomerular permeability factors in idiopathic nephrotic syndrome. Pediatric Nephrol. (2016) 31:207-15. doi: 10.1007/s00467-015-3082-x where all the complex cases are referred so it covers the whole country. Although we studied patients with the same ethnic background, it is actually a strength of our study because this type of genetic association has not been performed in any population in the Gulf Region. We studied the homozygous and the heterozygous genotypes. The allele frequencies in the homozygous and heterozygous forms were included.

In conclusion, we report no association between IL-4 and IL13 gene polymorphisms and the predisposition of INS in Kuwaiti Arab children. Of note, IL-13 RQ genotype was expressed more in children with INS who are steroid sensitive. Further larger studies, involving samples of different ethnic backgrounds, are warranted to determine the genetic predisposition of INS, as well as, steroid responsiveness in children.

\section{DATA AVAILABILITY STATEMENT}

The raw data supporting the conclusions of this article will be made available by the authors, upon request.

\section{ETHICS STATEMENT}

The studies involving human participants were reviewed and approved by Health Sciences Center committee for the protection of human subjects in research, Kuwait University, as well as, Ministry of Health ethics committee, Kuwait. Written informed consent to participate in this study was provided by the participants' legal guardian, patients and controls, as per the committees recommendations.

\section{AUTHOR CONTRIBUTIONS}

MA and AA-E: substantial contributions to conception and design. AA-E: acquisition of data. $\mathrm{MH}$ : gene studies and data analysis. MA and AA-E: interpretation of the results. MA and AA-E: drafting the article. AA-E and $\mathrm{MH}$ : revising it critically for important intellectual content. All authors: final approval of the version to be published.

\section{FUNDING}

This work was supported by Kuwait University General Support Project.

\section{ACKNOWLEDGMENTS}

We thank Kuwait University for providing funds for this study. The assistance of Mrs. Asiya T. Ibrahim in the statistical analysis and of Mrs. Jalaja Sukumaran in the lab work is thankfully acknowledged.
2. Parry RG1, Gillespie KM, Parnham A, Clark AG, Mathieson PW. Interleukin4 and interleukin-4 receptor polymorphisms in minimal change nephropathy. Clin Sci (Lond). (1999) 96:665-8. doi: 10.1042/cs0960665

3. Ikeuchi Y, Kobayashi Y, Arakawa H, Suzuki M, Tamra K, Morikawa A. Polymorphisms in interleukin-4-related genes in patients with 
minimal change nephrotic syndrome. Pediatr Nephrol. (2009) 24:489-95. doi: 10.1007/s00467-008-1003-y

4. Cheung W, Wei CL, Seah CC, Jordan SC, Yap HK. Atopy, serum IgE, and interleukin-13 in steroid-responsive nephrotic syndrome. Pediatr Nephrol. (2004) 19:627-32. doi: 10.1007/s00467-004-1438-8

5. Fang X, Zhu Z, Yang S, Ji Y, Wang L. Association of IL-4 and IL-4 receptor gene polymorphisms with the risk, immunotherapeutic effects and prognosis of advanced renal cell carcinoma. Int J Clin Exp Med. (2016) 9:11449-57.

6. Luo Y, Ye Z, Li K, Chen R, Li S, Pang J. Associations between polymorphisms in the IL-4 and IL-4 receptor genes and urinary carcinomas: a meta-analysis. Int J Clin Exp Med. (2015) 15:1227-33.

7. Suppiah V, Goris A, Alloza I, Heggarty S, Dubois B, Carton H, et al. Polymorphisms in the interleukin- 4 and IL-4 receptor genes and multiple sclerosis: a study in Spanish-Basque, Northern Irish and Belgian populations. Int J Immunogenet. (2005) 32:383-8. doi: 10.1111/j.1744-313X.2005.00542.x

8. Chu H, Wang M, Yan F, Zhong D, Shi D, Ma L, et al. Polymorphisms in the IL-13 and IL-4R genes are associated with the development of renal cell carcinoma. Ann Oncol. (2012) 23:2114-21. doi: 10.1093/annonc/mdr607

9. Banchereau J, Briere F, Galizzi JP, Miossec P, Rousset F. Human interleukin 4. J Lipid Mediat Cell Signal. (1994) 9:43-53.

10. Wei CL, Cheung W, Heng CK, Arty N, Chong SS, Lee BW, et al. Interleukin13 genetic polymorphisms in Singapore Chinese children correlate with longterm outcome of minimal change disease. Nephrol Dialysis Transplantation. (2005) 20:728-34. doi: 10.1093/ndt/gfh648

11. Graves PE, Kabesch M, Halonen M, Holberg CJ, Baldini M, Fritzsch C, et al. A cluster of seven tightly linked polymorphisms in the IL-13 gene is associated with total serum IgE levels in three populations of white children. J Allergy Clin Immunol. (2000) 105:506-13. doi: 10.1067/mai.2000.104940

12. Liu X, Nickel R, Beyer K, Wahn U, Ehrlich E, Freidhoff LR, et al. An IL13 coding region variant is associated with a high total serum IgE level and atopic dermatitis in the German multicenter atopy study (MAS-90). J Allergy Clin Immunol. (2000) 106:167-70. doi: 10.1067/mai.2000.107935

13. Heinzmann A, Mao XQ, Akaiwa M, Kreomer RT, Gao PS, Ohshima K, et al. Genetic variants of IL-13 signaling and human asthma and atopy. Hum Mol Genet. (2000) 9:549-59. doi: 10.1093/hmg/9.4.549

14. Quirico-Santos T, Suppiah V, Heggarty S, Caetano R, Alves-Leon S, Vandenbroeck K. Study of polymorphisms in the interleukin-4 and IL-4 receptor genes in a population of Brazilian patients with multiple sclerosis. Arq Neuropsiquiatr. (2007) 65:15-9. doi: 10.1590/S0004-282X2007000100005

15. Shirakawa I, Deichmann KA, Izuhara I, Mao I, Adra CN, Hopkin JM. Atopy and asthma: genetic variants of IL-4 and IL-13 signaling. Immunol Today. (2000) 21:60-4. doi: 10.1016/S0167-5699(99)01492-9

16. Kidney Disease: Improving Global Outcomes (KDIGO) Glomerulonephritis Work Group. KDIGO Clinical Practice Guideline for Glomerulonephritis. Kidney Inter Suppl. (2012) 2:139-274.

17. Sambrook J, Fritsch EF, Maniatis T. Molecular Cloning: A Laboratory Manual. 2nd ed. New York, NY: Cold Spring Harbor Laboratory Press (1989).

18. Schotte H, Schiuter B, Rust S, Assmann G, Domschke W, Gaubitz M. Interleukin-6 promoter polymorphism $(-174 \mathrm{G} / \mathrm{C})$ in Caucasian German patients with systemic lupus erythematosus. Rheumatology. (2001) 40:393400. doi: 10.1093/rheumatology/40.4.393

19. Tripathi G, Jafar T, Mandal K, Mahdi AA, Awasthi S, Sharma RK, et al. Does cytokine gene polymorphism affect steroid responses in idiopathic nephrotic syndrome? Ind J Med Sci. (2008) 62:383-91. doi: 10.4103/0019-5359.44017

20. Kobayashi Y, Arakawa H, Suzuki M, Takizawa T, Tokuyama K, Morikawa A. Polymorphism of interleukin-4 related genes in Japanese children with minimal change nephrotic syndrome. Am J kidney Dis. (2003) 42:271-6. doi: 10.1016/S0272-6386(03)00652-8

21. Jun TY, Lee KU, Pae CU, Chae JH, Bahk WM, Kim KS, et al. Polymorphisms of interleukin-4 promoter and receptor gene for schizophrenia in the Korean population. Psychiatry Clin Neurosci. (2002) 53:283-8. doi: 10.1046/j.1440-1819.2003.01118.x

22. Kawashima T, Nogushi E, Arinami T, Yamakawa-Kobayashi K, Nakagawa H, Otsuka F, et al. Linkage and association of an interleukin 4 gene polymorphism with atopic dermatitis in Japanese families. J Med Genet. (1998) 35:502-4. doi: $10.1136 /$ jmg. 35.6 .502

23. Jafar T, Agrawal S, Mahdi A, Sharma RK, Awashti S, Agarwal GG. Cytokine gene polymorphism in idiopathic nephrotic syndrome children. Ind J Clin Biochem. (2011) 26:296-302. doi: 10.1007/s12291-011-0126-2

24. Gillespie KM, Anderson KL, Mathieson PW, Gillespie KM. Polymorphism not in the IL-13 gene promoter. Science. (1999) 286:1647. doi: 10.1126/science.286.5445.1647b

25. Tenbrock K, Schubert A, Stapenhorst L, Kemper MJ, Gellermann J, Timmermann $\mathrm{K}$, et al. Type I IgE receptor, interleukin 4 receptor and interleukin 13 polymorphisms in children with nephrotic syndrome. Clin Sci. (2002) 102:507-12. doi: 10.1042/cs1020507

26. Parry RG, Gillespie KM, Mathieson PW. Effects of type 2 cytokines on cultured human glomerular epithelial cells. Exp Nephrol. (2001) 9:275-83. doi: $10.1159 / 000052622$

27. Van den Berg JG, Aten J, Chand MA, Claessen N, Dijkink L, Wijdenes J, et al. Interleukin-4 and interleukin-13 act on glomerular visceral epithelial cells. J Am Soc Nephrol. (2000) 11:413-22.

28. Coers W, Vos JT, van der Meide PH, Van der Horst ML, Huitema S, Weening JJ. Interferon-gamma (INF-gamma) and IL-4 expressed during mercuryinduced membranous nephropathy are toxic for cultured podocytes. Clin Exp Immunol. (1995) 102:297-307. doi: 10.1111/j.1365-2249.1995.tb03781.x

29. Van der Berg JG, Aten J, Annink C, Ravesloot JH, Weber E, Weening JJ. Interleukin-4 and interleukin-13 promote basolateral secretion of $\mathrm{H}(+)$ and cathepsin L by glomerular visceral epithelial cells. Am J Physiol Renal Physiol. (2002) 282:F26-33. doi: 10.1152/ajprenal.0102.2001

30. Lai KW, Wei CL, Tan LK, Tan PH, Chiang GS, Lee CG, et al. Overexpression of interleukin-13 induces minimal-change-like nephropathy in rats. J Am Soc Nephrol. (2007) 18:1476-85. doi: 10.1681/ASN.2006070710

31. Youn SY, Lim HH, Lee HJ. The clinical of steroid responsive nephrotic syndrome of children according to the serum immunoglobulin E levels and cytokines. Yonsei Med J. (2012) 53:715-22. doi: 10.3349/ymj.2012. 53.4.715

32. Veissi S, Smeets B, Heuvel LP, Schreuder MF, Jansen J. Nephrotic syndrome in a dish: recent developments in modeling in vitro. Pediatric Nephrol. (2020) 35:1363-72. doi: 10.1007/s00467-019-4203-8

Conflict of Interest: The authors declare that the research was conducted in the absence of any commercial or financial relationships that could be construed as a potential conflict of interest.

Copyright (c) $2020 \mathrm{Al}$ Rushood, Al-Eisa and Haider. This is an open-access article distributed under the terms of the Creative Commons Attribution License (CC BY). The use, distribution or reproduction in other forums is permitted, provided the original author(s) and the copyright owner(s) are credited and that the original publication in this journal is cited, in accordance with accepted academic practice. No use, distribution or reproduction is permitted which does not comply with these terms. 